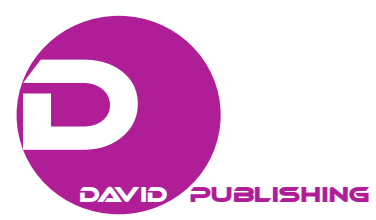

\title{
Celebrity Endorsement and Consumer Buying Intention With Relation to the Television Advertisement for Perfumes
}

\author{
Roshan Priyankara, Sudath Weerasiri, Ravindra Dissanayaka, Manoj Jinadasa \\ University of Kelaniya, Kelaniya, Sri Lanka
}

\begin{abstract}
This present paper explores the celebrities appearing on television advertisements. The purpose is to identify the influence of celebrity endorsement on consumer buying intention in Sri Lanka. Television Advertising is one of the marketing communication tools used to receive the attention of the customer and build their loyalty to perfume brands. Celebrity advertisement is an important and frequently used marketing tool to directly influence the consumers' purchase intentions. The aim of this study is to determine the effect of celebrity endorsement on customer purchasing intention for perfume brands. The survey method was used as the research method. Questionnaire was utilized in gathering information from the respondents in Colombo and Gampaha in Sri Lanka. Cluster sampling was used to select a sample size of 100 and collected data were analyzed descriptively using the SPSS 20.0 version. Correlation analysis was conducted to establish the nature of the relationship between the celebrity endorsers and consumer purchasing intention. Results showed significant relationship between the celebrity endorsement (likability, credibility, personality, attractiveness, and expertise) and consumer purchasing intention, so that all five hypotheses were accepted by this exploration.
\end{abstract}

Keywords: celebrity endorsement, likability, personality, attractiveness, credibility, expertise and consumer purchasing intention

\section{Introduction}

Ancient tombs have proven that fragrance played a part in the lives of ancient Egyptians dating back as far as King Menes in around 3500 and 3000 BC. In ancient times, burning incense and sweet herbs was the privilege of priests in the earliest civilizations. It was these ceremonial burnings that gave perfume its name. In Roman times, worship to the gods took place "per fumum”, meaning "through smoke”. It was this Latin phrase

\footnotetext{
* Acknowledgements: I am indebted to all the assistants who help me in data collection and analysis, so that I was possible to conclude this study in this international publication.

* No potential conflict of interest was reported by the authors.

Roshan Priyankara, professional model/commercial actor (MBM pending), Department of Marketing Management, Faculty of Commerce and Management, University of Kelaniya, Kelaniya, Sri Lanka.

Sudath Weerasiri, senior lecturer (Ph.D.), Department of Marketing Management, Faculty of Commerce and Management, University of Kelaniya, Kelaniya, Sri Lanka.

Ravindra Dissanayaka, senior lecturer (Ph.D. pending), Department of Marketing Management, Faculty of Commerce and Management, University of Kelaniya, Kelaniya, Sri Lanka.

Manoj Jinadasa, senior lecturer (M.S.Sc.), Department of Mass Communication, Faculty of Social Sciences, University of Kelaniya, Kelaniya, Sri Lanka.

Correspondence concerning this article should be addressed to Manoj Jinadasa, Department of Mass Communication, Faculty of Social Sciences, University of Kelaniya, Kelaniya, Sri Lanka.
} 
which became the modern word "perfume".

Perfumes have been known to exist in some of the earliest human civilizations, either through ancient texts or from archaeological digs. Modern perfumery began in the late 19th century with the commercial synthesis of aroma compounds such as vanillin or coumarin, which allowed for the composition of perfumes with smells previously unattainable solely from natural aromatics alone.

In recent years, celebrities have signed contracts with perfume houses to associate their name with a signature scent, as a self-promotion campaign. The scents are then marketed; the association with the celebrity's name usually being the selling point of the campaign. Such products generally do not have the longevity of classic fragrances. A notable exception is "White Diamonds", endorsed by Elizabeth Taylor and made and marketed by Elizabeth Arden. It was still the best-selling celebrity-endorsed perfume for 20 years after its introduction in 1991. In 2013, it was revealed that Beyoncé's line of perfumes heat is the best-selling celebrity fragrance line with $\$ 400$ million earned at retail globally.

Television is the most effective medium for reaching today's customers and it is also the most efficient for introducing brands to consumers (M. P. K. Jinadasa, 2011b; 2014a; W. W. M. P. K. Jinadasa, 2015). M. P. K. Jinadasa (2014b) stressed that the advertising through television allows marketers to show their business, product, or service and communicate with a wide audience. It allows one to actually demonstrate the benefits of ownership. Television appeals to the literate as well as the illiterate and this is one feature of TV that makes it unique and different from other media.

As M. P. K. Jinadasa (2011a) and M. Jinadasa (2015) have pointet out, in this age of globalization, technology has shaped the possibility and likelihood of the global culture. The use of the internet, satellites, and cable TV is wiping out cultural boundaries. Global entertainment companies have given form to the perceptions and the ideals of ordinary citizens, wherever they live. This spread of values, norms, and culture tends to promote western, particularly American, ideals (M. Jinadasa, 2016b).

The use of celebrities, in order to increase the sales and/or the recall value of a brand, is called celebrity endorsement. According to H. H. Friedman and L. Friedman (1979), a "celebrity endorser is an individual who is known by the public for his or her achievements in areas other than that of the product class endorsed”.

In Hollywood and Bollywood, the entertainment industries are based on the creation of stars and leading icons that have had a very significant influence on the public. Public fascination of celebrities and the extravagant lifestyles they lead have had a widespread influence on fashion and popular culture (M. P. K. Jinadasa, 2009; 2013). Through wider access to the internet and intrusive media, people worldwide are highly updated on the latest trends in Hollywood, or the latest launches and scandals in the music industry (M. Jinadasa, 2016a).

Due to the immense availability of media, the emergence of a new stage of commercial communication has taken place. Companies are constantly finding new ways in which they can communicate with their consumers in both a conscious level and subconscious level by surrounding customers with constant brand messages. At a conscious level, the consumers choose the communications they are interested in (M. P. K. Jinadasa, 2011b). If they are looking for a specific product or service of interest, they will selectively perceive relevant brand messages. The battle for a piece of the consumers "mind space" has made companies want to associate their brands with desirable and trustworthy celebrities in order to attract consumers' attention and interest. The use of celebrities as means of communication has been commonly utilized in advertising and branding. This is done because it is assumed that celebrities have a powerful effect on the affluence of the 
brands they endorse. Celebrity endorsement has been defined as: "any individual who enjoys public recognition and who uses this recognition on behalf of a consumer good...” (Byrne \& Breen, 2003). Research statistics has shown that the use of celebrity advertisement has doubled in the past 10 years, which is statistically related to the consumer goods industry. One in four adverts features celebrities as opposed to one in eight in 1995. An increase in the use of celebrities in brand message communication between non-luxury brands and luxury brands has taken place.

Celebrities are brands in themselves, and in recent years, the amount of celebrities that have launched fragrances in their names or endorsed a fragrance escalated. According to McCracken (1989), a celebrity endorser is an "individual who is known by the public for his or her achievements in areas other than that of the product class endorsed".

Many celebrities see the multibillion dollar fragrance market as a lucrative way to expand their already famed brand, their name. Celebrities that were formerly associated with the music industry or/and film industry are exposing their presence in the consumer market, particularly the fragrance market. The scents are marketed with the celebrity's name being the selling point. Celebrities are taking the opportunities to make full benefits of their fame whilst it lasts, and therefore want consumers to listen to their music, watch their movies, buy garments from their latest launched clothing line, and indulge their latest signature perfumes.

The fragrance industry has been fragmented, due to multiple reasons and because of increased competition leading to low fragrance life-spans. Fragrance houses are finding creative ways to secure their market shares and boost their sales figures. Expansion strategies such as mergers are common. Another strategy fragrance houses have been employing is celebrity endorsement branding. They cooperate with a celebrity and register trademark, a scent under the celebrity's name. In that sense, they can compete with both their classical fragrances (premium branded fragrances) and the more juvenile oriented celebrity endorsed fragrances.

\section{Research Problem}

Studies have shown the use of celebrity endorsers can create a more positive response as well as a higher purchasing intention than non-celebrity endorsers. Industry experts claim sales increase will boost due to the more common availability of celebrity endorsed fragrances that are attracting a younger consumer group.

Advertisers have recognized the value of using celebrities in their advertisements. Celebrities appear in their advertisements and endorse their products. Marketers think a popular admired celebrity will favorably influence consumer's feeling and purchase intention. Shaughnessy (1995, p. 982) opined that "the use of celebrities tends to produce above average brand awareness but only about half of the celebrities have a positive effect on consumer's buying intention towards the product”.

Every celebrity advertising campaign does not equally work. Some of them are very effective and some not at all (Dissanayaka \& Ismail, 2015). In the context of Sri Lanka, there has been practicing celebrity advertising especially with the television commercials, nobody has conducted a comprehensive study on the effectiveness of the celebrity endorsed advertising.

Therefore, research problem of this study is:

"How far celebrity endorsement influences consumer’s buying intention towards perfumes".

\section{Research Objectives}

Key objective. With the background in thought, it would be of interest to examine the effects of celebrity endorsed branding on consumers' purchasing intention. The aim of this study is to identify the influence of 
celebrity endorsement on consumer's buying intention.

\section{Specific objectives.}

(1) To study the consumers' attitude towards “celebrity endorsed fragrances" and "Premium branded fragrances”.

(2) To identify the effects of celebrity endorsed branding of fragrances have on consumers purchasing behavior.

(3) To examine life style behavior change because of the perfume brands.

Research questions. The questions that then arise are:

How is the consumers' attitude towards "celebrity endorsed fragrances" versus "Premium branded fragrances”?

What effects does celebrity endorsed branding of fragrances have on consumers purchasing behavior?

How does life style behavior change because of the perfume brands?

\section{Significance of the Study}

Perfume industries are possible in gaining substantial level of profit through creating eye-catching perfume advertisements, so that there is an important relationship between celebrity endorsement and its affection to buying intention.

Selecting right celebrity in advertisement is critical.

\section{Research Methodology}

\section{Sample Size}

This research used the quantitative methodology. In the quantitative methodology, basically, the authors used the survey study, which equipped questionnaire for the data collection. This questionnaire administered to a convenient sample that amount one hundred (100) subjects. In this survey, it used one hundred (100) questionnaires covering university undergraduates and the executive level professionals in the Gampaha and Colombo districts. Subjects were limited only to male. Age categorized from 25 to 35.

\section{Collection of Data}

Data collected using the questionnaire method among hundred subjects. Thirty eight questions were included in the questionnaire covering both demographic and research objective data. For the data collection mechanism, the authors used five data collectors as research supporters who are very close with the sample and its socio-cultural behaviors. Fourteen days were allocated for the field survey in the data collection. There were two levels of data collection. First, questionnaires were distributed among the subjects and in second, they were asked to fill it as they wished to complete it at their leisure without any pressure. Finally, filled questionnaires were collected by the five research assistants of data collection.

\section{Analysis of Data}

Collected data were analyzed statistically using SPSS 20.0 version and descriptive methods were used to analyze the gathered data. Thirty eight questions were based to make the SPSS program for the primary data feeding to SPSS program. For this, technical assistance was made by two data analysts.

In the data analyzing, descriptive methods were used in the SPSS program along with the basic research objectives and questions. Hypotheses were tested through the use of descriptive data analyses along with the conceptual frame-work created from the end of the literature review. In the presentation of data, in addition to the basic statistical figures found, bar charts and scattered tables were created for the effectiveness of data 
presentation.

\section{Limitations of the Study}

This research was limited to its field of study and the scope of selection of sample. In the collection of data, even it is used both questionnaire and interview methods, subjects could be answered in bias and in terms of their personal subjectivities, which is quite impossible to receive their real ideas, so it is also a limitation of this study.

For the convenience of making this research, it used fundamentally both two categories of undergraduates and executives are also a limitation of this research as the variables of consumer buying intention.

\section{Literature Review}

\section{Celebrity Endorsement}

A celebrity endorser is "an individual who enjoys public recognition and who uses this recognition on behalf of a consumer good by appearing with it in an advertisement” (McCracken, 1989, p. 310). As H. H. Friedman and L. Friedman (1979, p. 63) stated, "a celebrity endorser is an individual who is known to the public for his or her achievement in areas others than of the product class endorsed”.

In this paper, celebrity endorsement will be further explored with the use of several determinants. This section describes which factors a celebrity should have to be a solid endorser. To explain the determinants of celebrity endorsement, this study will look at the determinants illustrated by Amos, Holmes, and Strutton (2008). Moreover, the source credibility model and the source attractiveness model will be used as foundation for selecting the determinants (Erdogan, 1999). The determinants described in this paper are: credibility, expertise, trustworthiness, attractiveness, similarity, liking, familiarity, and the match-up congruence with the product. Source credibility depends on expertise and trustworthiness. Source attractiveness depends on familiarity, liking, and similarity.

\section{Likability}

Likeability is the "affection for the source as a result of the source's physical appearance and behavior" (McGuire, 1985, p. 239). In addition, McGuire (1985) stated that when people like the celebrity they will also like the accompanying brand and therefore celebrities are used in commercials and advertisements. Celebrity endorsement will influence the consumer's behavior and attitude (G. E. Belch \& M. A. Belch, 2008) and advertisers believe that a celebrity can influence the consumer's vision of the company's image. In the view of Kahle and Homer (1985), the process of the disliked celebrity is explained in an experiment that contained a total of 200 men and women participating in the study. The experiment contains the example of celebrity endorsement used with disposable razors by means of John McEnroe; he has been the celebrity endorser for this particular brand. John McEnroe is a tennis player who can annoy people; his extreme rough language on the tennis court is widely known. It can be stated that he is not the ideal endorser of a brand, and that John McEnroe can be assigned to the disliked celebrity group. The company retains him because his image implies concern for protection of self-interest; two factors the company wants consumers to be associated with regarding the consumption of disposable razors. Despite McEnroe is a disliked celebrity, the company uses him as an endorser.

\section{Credibility}

Credibility is "the extent to which the recipient sees the source as having relevant knowledge, skills, or experience and trusts the source to give unbiased, objective information” (G. E. Belch \& M. A. Belch, 2008). 
The two most important aspects of credibility are expertise and trust (Hovland \& Weiss, 1953). Celebrities are seen as credible sources of information (Goldsmith, Lafferty, \& Newell, 2000) and the credibility of a celebrity is described as the total amount of positive features that create and increase the acceptation of the message (Erdogan, 1999). Credibility is one of the most important determinants of celebrity endorsement. Credibility is particularly important when people have a negative attitude towards the brand and powerful arguments are needed to inhibit the counter arguing and positively influence the attitude towards the brand. Consequently, when celebrities are credible, it affects the acceptance of the message and the persuasion (G. E. Belch \& M. A. Belch, 2008).

\section{Personality}

The celebrity-persona parasocial identification scale (CPI) is designed to measure how media consumers develop identification with celebrities or popular fictional characters. Identification is defined as a persuasion process that occurs when an individual adopts the behavior or attitudes of another individual or group based on a self-defining relationship (Kelman, 1961, p. 63). Identification is a psychological orientation through which individuals define themselves based on their group membership and derive "strength and a sense of identity" from the affiliation (Kelman, 1961, p. 64). Identification is a fundamental process of social change that has been discussed by several important theorists and social scientists. Freud (1922, p. 29) defined identification as "the earliest expression of an emotional tie with another person." Lasswell (1965) also discussed the concept, referring to mass identifications such as nationalism. W. L. Johnson and A. B. Johnson (1995) traced the concept of identification to both Freud (1922) and Lasswell (1965).

\section{Attractiveness}

The concept of attractiveness does not only entail the physical attractiveness. Attractiveness also entails concepts such as intellectual skills, personality properties, way of living, athletic performances, and skills of endorsers (Erdogan, 1999). Celebrities can be attractive because they established for example great sport performances and people have great respect for their achievement and therefore they are attracted to them. Physical attractiveness suggests that a celebrity determines the effectiveness of persuasion as a result of that consumers want to be like the endorser and want to identify themselves with that endorser (Cohen \& Golden, 1972). In addition, there are examples of celebrities who are considered less attractive, but do represent the image the company wants to create and have. When the match-up between brand and celebrity is present, attractiveness becomes less important and therefore the company might choose a less attractive celebrity. There are huge numbers of physical attractive celebrities who endorse a product. An example is David Beckham for the Armani brand. The majority of people are attracted by David Beckham. Men want to be associated with the soccer player and fashion man David Beckham, while woman are physically attracted by his appearance because David Beckham always looks fashionable and has great athletic performances. He is extremely credible and attractive and has a high degree of similarity; people want to be like him.

\section{Expertise}

Expertise of celebrity endorsement is being defined as "the extent to which an endorser is perceived to be a source of valid assertions” (Erdogan, 1999, p. 298). With regard to expertise, it is not important that the celebrity is really an expert in the field. It is important that consumers think and believe a celebrity has expertise (Ohanian, 1991).

To illustrate, in a selling context, an expert salesperson caused a significantly higher number of customers 
to purchase a product than the non-expert salesperson did (Woodside \& Davenport, 1974). Expert sources also influence perceptions of the product's quality. The source or celebrity that is a specialist has been found to be more persuasive (Aaker, 1997) and generates more purchase intentions (Ohanian, 1991). Furthermore, Speck, Schumann, and Thompson (1988) stated that celebrities, who are seen as an expert in a specific area, engender a higher brand recognition than celebrities who are seen as non-experts. The level of celebrity expertise will determine its effectiveness (Amos et al., 2008). The more expertise a celebrity has, the more effective it will be. The expertise of a celebrity will not be changed by negative publicity, but the believability and credibility will be negatively influenced.

\section{Consumer Buying Intention}

According to H. H. Friedman and L. Friedman (1979), "a celebrity endorser is an individual who is known by the public for his or her achievements in areas other than that of the product class endorsed”. Compared to other endorser types, famous people always attach a greater degree of attention, recall, and loyalty.

According to Melissa St. James, a doctoral fellow and marketing instructor at The George Washington University, "Studies show that using celebrities can increase consumers' awareness of the ad, capture (their) attention and make ads more memorable”. Diverse literature is available on celebrity endorsement.

Klebba and Unger (1983) used multiple regression analyses to examine the impact of positive and negative source information on the credibility of the advertising source and on audience perceptions of the company and advocated product. The results of their study indicate that the cognitive and affective dimensions of credibility are influenced differently by negative information.

Wenqian Gan (2006) explored the Chinese consumer's behaviors toward celebrity and non-celebrity commercials. The results show that Chinese consumers prefer celebrity commercial and respondents collectively like celebrity who have more professional career skill, even though there are other different reasons existing such as good appearances, good disposition, and good career spirit.

Hunter and Davidsson (2008) studied negative information's impact on celebrity entrepreneurship. There results show that negative information about the celebrity might lead to negative attitude towards the new venture and promotion, new ventures can potentially reduce damage to their brand by distancing themselves from the celebrity, however, such a maneuver may not be as effective when the new venture is run by a celebrity entrepreneur.

Schlecht (2003) examined the relationship between celebrity endorsements and brands, by applying a selection of widely accepted principles of how consumers' brand attitudes and preferences, it can be positively influenced. Thereby, the concepts of source credibility and attractiveness, the match-up hypothesis, the meaning transfer model, and the principles of multiple product and celebrity endorsement were used. A brief assessment of the current market situation indicates that celebrity endorsement advertising strategies can under the right circumstances indeed justify the high costs associated with this form of advertising. Several failures show, it is essential for advertisers to be aware of the complex processes underlying celebrity endorsement.

Khatri (2006) studied celebrity endorsement as strategic promotion. An assessment of current market situation indicated that celebrity endorsement and advertising strategies, if correctly blended in terms of marrying the strengths of the brands with the celebrity's quality, indeed justify the high cost associated with this form of advertising. However, advertising needs to be aware of the complex processing underlying celebrity processing endorsement by gaining clarity on described concepts of celebrity source creditability and 
attractiveness, match-up hypothesis, multiple product endorsement, etc. Marketer has to decide how far the benefits outweigh the risks associated. Advertisers agree that celebrity endorsement does not itself guarantee sales. It can create a buzz and make a consumer feel better about the product, which in turn has to come to expectation of customers as a real star by delivering the promise (Weerasiri \& Wanninayaka, 2016). There have been instances where the endorsement or real consumer has started working better than celebrity endorsers. In fact, many researches need to be done on customer testimonials, which tends to induce better creditability and helps in carving the competent, rational, and knowledgeable customer of today who is said to be the real hero.

Money, Shimp, and Sakano (2006) studied the impact of negative information of celebrity on brand. They conducted comparative study in the US and Japan to investigate whether the form of negative information about a celebrity (other- or self-oriented) results in differential evaluations of the brand endorsed by the celebrity. Surprisingly, the authors find that both Japanese and Americans view endorsed products more positively in the presence of self-oriented negative information, a possible suspension of the famous fundamental attribution error in human judgment.

Escalas and Bettman (2010) studied consumers appropriate brand symbolism that comes from celebrity endorsement to construct and communicate their self-concepts. Study 1 finds that celebrity endorsement enhances self-brand connections when consumers aspire to be like the celebrity, but harms them when consumers do not; this effect is more pronounced when the brand image is congruent with the celebrity's image. This effect is further moderated by the degree to which a brand communicates something about the user, with more symbolic brands having stronger effects than less symbolic brands. Study 2 finds that the effect of celebrity endorsement on self-brand connections is augmented when consumers' self-esteem is threatened. Consumers self-enhance by building connections to favorable celebrity images or distancing themselves from unfavorable celebrity images.

Silvera and Austad (2004) examined the characteristics of advertisements that make them effective are especially valuable. The present experiments represent a first step in identifying what makes endorsement advertisements effective based on work in attribution theory within social psychology. The results suggest that endorsement advertising effectiveness can be strongly influenced by consumers' inferences concerning whether the endorser truly likes the product. Advertisers often appear to be satisfied with merely creating an association between a popular endorser and their product with the hope that the endorser's positive image will somehow "rub off" on the product. The present research suggests that advertisers should put more effort not only into choosing endorsers who are well match with products, but also into making strong arguments and believable explanations for why endorsers truly do like the products they endorse.

Mukherjee (2009) analyzed the impact of celebrity endorsements on brands. Objective of this article is to examine the relationship between celebrity endorsements and brands, and the impact of celebrity endorsement on consumer's buying behavior as well as how consumer makes brand preferences. This paper proposes a 20 points' model which can be used as blue-print criteria and can be used by brand managers for selecting celebrities and capitalizing the celebrity resource through 360 degree brand communication which, according to this paper, is the foundation of the impact of celebrity endorsement. Celebrity endorsement is always a two-edged sword and it has a number of positives-if properly matched, it can do wonders for the company; and if not, it may produce a bad image of the company and its brand.

The "meaning" of a brand resides in the minds of consumers, based on what they have learned, felt, seen, and heard overtime. This study explores the relationship between quality and image with special attention on 
brands plagued with negative impressions, including instances where consumers' perceptions of a product's quality conflict with its perceived "image”. Data confirm that quality and image impact attitudes in a distinct manner, and overall, low brand image is more damaging than low quality. In addition, findings show that: (1) hedonic attitudes towards brands are most driven by image, whereas utilitarian attitude formation/change processes are dominated by quality, (2) non-attribute brand beliefs are a stronger predictor of hedonic attitudes when quality or image is low versus high, while (3) attribute-based beliefs are strong predictors of utilitarian attitudes across image and quality levels.

Saleem (2007) has clarified celebrity endorsement that is becoming very prominent in nowaday. Marketers use celebrities in ads when there is no or very little product differentiation. When marketers have to target more diverse market multiple celebrities endorsement (more than one celebrity in a single ad), there could be an answer. The purpose of the current study is to explore the perceptual difference of young adult toward single celebrity ads and multiple celebrities' ads. Questionnaires were administered on a sample of 300 university students to asses if there is any difference in young adult's perception about single celebrity endorsement and multiple celebrities' endorsement. Four print media ads, two containing one celebrity in them and two containing three and five celebrities in them, were used as a stimulus. The results showed that the attitude toward ad and purchase intentions are more positive for multiple celebrities ads compare to single celebrity ads and there is no significant difference in the attitude toward brand for multiple celebrities ads and single celebrity ads.

\section{Theories}

This section presents the theories behind this study. The theories used will be Kelman's Model of Source Characteristics, The ABC Model of Attitudes, and Hierarchy of Effects.

\section{Motivation of Chosen Theories}

This study aims to examine consumers' attitude towards celebrity endorsed fragrances in comparison to premium fragrance brands. Considering the fact that the perspective viewed upon in this study is a consumer oriented one, it is of interest to bring up a consumer behavior model such as The ABC Model of Attitudes and Hierarchy of Effects. This is necessary to get a deeper understanding of perfume consumers attitude formation and behavior. The other model presented, Kelman's Model of Source Characteristics, will give a deeper understanding of how a celebrity can have influence on perfume consumers' attitudes and behavior.

\section{Kelman's Model of Source Characteristics}

There is a full description of Kelman's model of source characteristics. According to the source characteristics model, different words uttered or written by different sources can have different outcomes. The source of the message can have a big impact on the likelihood of the message being accepted. The choice of a source to maximize attitude change can tap into different dimensions. The source can be chosen because he or she is an attractive, famous, expert or even a regular consumer who is pleasant and trustworthy. There should be a match between the needs of the receiver and the potential rewards offered by the source. When this match occurs, the receiver is more motivated to accept the message. A positive source can help to reduce risk and increase message acceptance overall. Two source characteristics of importance are credibility and attractiveness. Each characteristic of the source has some kind of influences on attitudinal or behavioral change in a consumer.

\section{Source Credibility}

Source credibility refers to a source's perceived, objectivity expertise, or trustworthiness. This relates to 
the consumers' beliefs that a communicator is competent, and she or he is willing to provide the necessary information to adequately evaluate competing products. A source that is credible can be particularly persuasive when the consumer has not yet learned much about merchandise or formed an attitude of it. Credibility can be enhanced if the source's credentials are perceived as somehow applicable to the product being endorsed. This association can overcome other objections people may have to the endorser or the product.

\section{Source Attractiveness}

Source attractiveness relates to the source's perceived social value. This quality can originate from the persons physical appearance, social status personality, or his or her similarity to the receiver. A persuasive source has great value and endorsement deals are continuous in the works. A physically attractive source has a tendency to facilitate attitude change. His or her extent of attractiveness puts forth modest effects on consumers purchase intentions. Beauty can also work as a source of information. An attractive representative or spokesperson is an effective source when the merchandise is related to attractiveness.

\section{The ABC Model of Attitudes and Hierarchy of Effects}

Solomon (2002) described the ABC model of attitudes as a multidimensional perspective stating that attitudes are jointly defined by affect, behavior, and cognition. Affect refers to the way a consumer feels about an attitude object. Behavior involves the person's intentions to an attitude object. Cognition refers to the beliefs a consumer has about an attitude object. This model emphasizes the interrelations among knowing (cognition), feeling (affect), and doing (behavior). All three components of an attitude are important, but their relative importance will vary depending on a consumers' level of motivation with regard to the attitude object. The concept hierarchy of effects explains the relative impact of the three components. Each hierarchy specifies that a fixed sequence of steps occurs en route to an attitude.

\section{Conceptualization and Operationalization}

\section{Conceptual framework.}

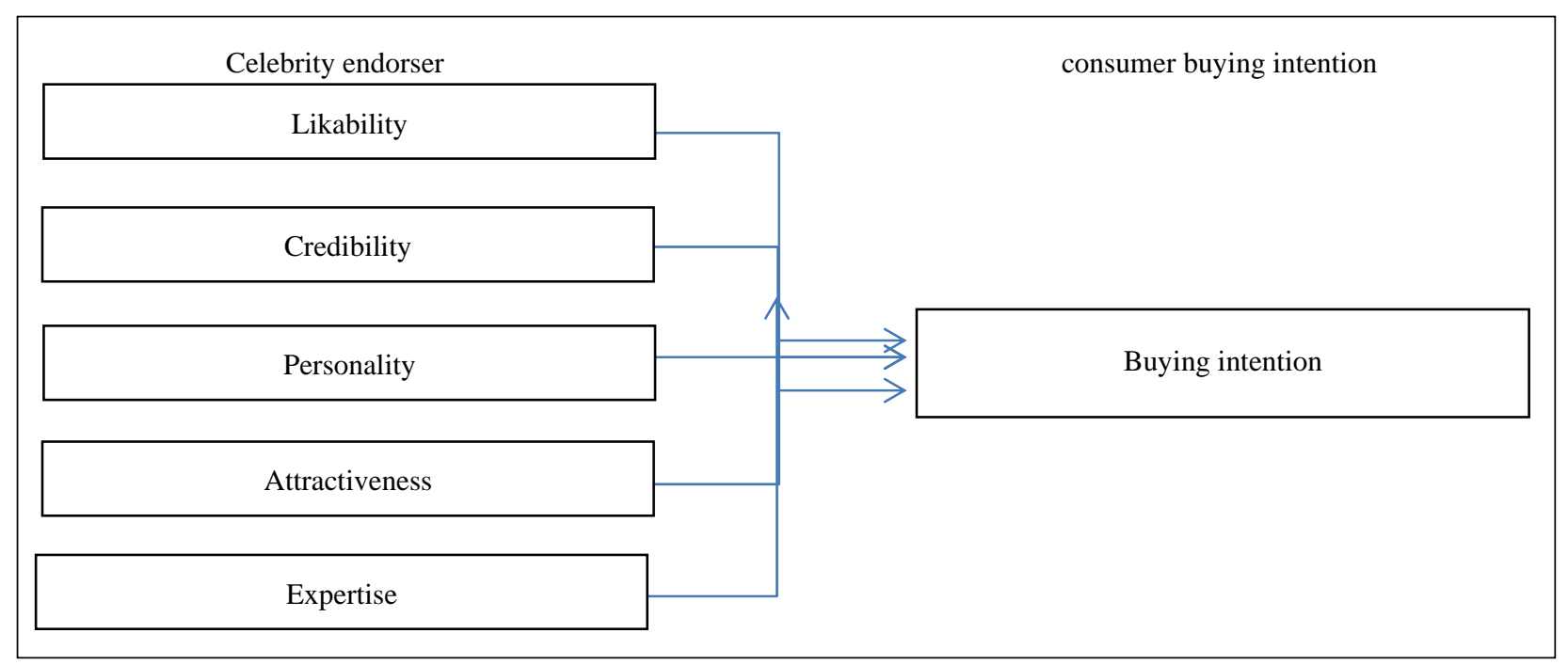

Figure 1. Conceptual framework.

\section{Hypotheses}

Based on the literature review, basic dependent variables were identified (Figure 1). likability (McGuire, 1985, p. 239; G. E. Belch \& M. A. Belch, 2008; Kahle \& Homer, 1985), credibility (G. E. Belch \& M. A. Belch, 
2008, p. 189; Hovland \& Weiss, 1953; Goldsmith et al., 2000; Erdogan, 1999), personality (Kelman, 1961, p. 63; Freud, 1922, p. 29; Lasswell, 1965; W. L. Johnson \& A. B. Johnson, 1995), attractiveness (Erdogan, 1999; Cohen \& Golden, 1972), and expertise (Erdogan, 1999, p. 298; Ohanian, 1991; Woodside \& Davenport, 1974; Aaker, 1997; Ohanian, 1991; Speck et al., 1988; Amos et al., 2008). Hence, the hypotheses as follows were created and formulated based on these literatures.

Hypothesis 1: The celebrity endorser’s perceived likability will positively influence purchase intention for consumers.

Hypothesis 2: The celebrity endorser's perceived credibility will positively influence purchase intention for consumers.

Hypothesis 3: The celebrity endorser's perceived personality will positively influence purchase intention for consumers.

Hypothesis 4: The celebrity endorser's perceived attractiveness will positively influence purchase intention for consumers.

Hypothesis 5: The celebrity endorser's perceived expertise will positively influence purchase intention for consumers.

\section{Operationalization}

The concept of this study is defined and discussed in the literature review. In addition, the researcher paid attention to the previous work that has been done on this concept. With the help of these opinions and views as well as the research findings, the researcher identified key variables which mostly affect the consumer behavior as a result of introducing celebrity in the advertisements. Based on this information, the operationalization process was done. In this context, the researchers try to identify indicators of research variables and their measurement criteria (Table 1).

Table 1

Operationalization and Variables

\begin{tabular}{|c|c|c|}
\hline Variable & Indicator & Measurement \\
\hline Likability & $\begin{array}{l}\text { - Pleasing } \\
\text { - Affection } \\
\text { - Veracity } \\
\text {-Believable }\end{array}$ & $\begin{array}{l}\text { Consumer's attitude of whether the celebrity has the power of satisfaction. } \\
\text { Consumer's attitude of whether the celebrity has the power of strong feelings/emotions. } \\
\text { Consumer's attitude of whether the celebrity has the power of conveying the truth. } \\
\text { Consumer's attitude of whether the celebrity is believable. }\end{array}$ \\
\hline Credibility & $\begin{array}{l}\text { - Confidence } \\
\text { - Honest } \\
\text { - Sincerity } \\
\text { - Strength }\end{array}$ & $\begin{array}{l}\text { Consumer's attitude about confidence of the celebrity. } \\
\text { Consumer's attitude of whether the celebrity is honest. } \\
\text { Consumer's attitude on the sincerity of the celebrity. } \\
\text { Consumer's attitude about moral courage of celebrity. }\end{array}$ \\
\hline Personality & $\begin{array}{l}\text { - Courage } \\
\text { - Good look } \\
\text { - Know-how } \\
\text { - Skill }\end{array}$ & $\begin{array}{l}\text { Consumer's attitude whether the celebrity has moral courage. } \\
\text { Consumer's attitude whether the celebrity outlook. } \\
\text { Consumer's attitudes whether the celebrity is technically sound. } \\
\text { Consumer's attitude whether the celebrity can use his or her knowledge effectively in its } \\
\text { specialized area. }\end{array}$ \\
\hline Attractiveness & $\begin{array}{l}\text { - Appearance } \\
\text { - Desire } \\
\text { - Attention } \\
\text { - Interest } \\
\end{array}$ & $\begin{array}{l}\text { Consumer's attitude of the celebrity's external outlook. } \\
\text { Consumer's attitude of whether he or she prefer to the celebrity. } \\
\text { Consumer's attitude of celebrity's ability to hold the attention. } \\
\text { Consumer's attitude whether interest or not the celebrity character. }\end{array}$ \\
\hline Expertise & $\begin{array}{l}\text { - Knowledge } \\
\text { - Experience } \\
\text { - Authority } \\
\text { - Training }\end{array}$ & $\begin{array}{l}\text { Consumer's attitude whether the celebrity has practical knowledge on his or her specialized area. } \\
\text { Whether the celebrity has sufficient experience in his or her field or area. } \\
\text { Consumer's attitude whether the celebrity has power to influence others action or behavior. } \\
\text { Consumer's attitude whether the celebrity has obtained a practical training relevant to his or } \\
\text { her field. }\end{array}$ \\
\hline
\end{tabular}




\section{Consumer Buying Intention}

Table 2

Consumer Buying Intention

\begin{tabular}{|l|l|l|}
\hline Variable & Indicator & Measurement \\
\hline \multirow{4}{*}{$\begin{array}{l}\text { Consumer } \\
\text { buying } \\
\text { intention }\end{array}$} & Selecting & Consumer's attitude of whether the celebrity can help him or her to select good or services. \\
\cline { 2 - 3 } & Purchasing & Consumer's attitude of whether the celebrity can influence the consumer's purchasing intention. \\
\cline { 2 - 3 } & Using & Consumer's attitude of whether the celebrity influenced him or her to use good and service. \\
\cline { 2 - 3 } & Evaluating & Consumer's attitude of whether the celebrity can help him or her to evaluate products. \\
\cline { 2 - 3 } & Disposing & Whether consumer has disposed products according to the celebrities' opinions. \\
\hline
\end{tabular}

\section{Methodology}

\section{Field of the Research and Sample}

This research used quantitative methodology. In the quantitative methodology, basically, the authors use a survey study which uses questionnaire for the data collection.

Study field is both television commercial and buying behavior. In this, for the survey, it used 100 questionnaires covering university undergraduates and the executive level professionals in the Gampaha and Colombo districts. Method of convenient sampling is used for this survey.

\section{Research Approach}

As the objective of this study is to explore the attitudes and purchasing intention of perfume consumers, a quantitative approach is utilized. A quantitative research is utilized to measure a particular phenomenon, so they can be transformed to numbers. Quantitative research examines numerical relations between two or more measurable qualities. Such an approach is usually associated with large-scale studies and is related to the objectivity of the researcher. Quantitative research on the other hand relies on transforming the observed phenomena to written words instead of numbers. A combination of a holistic perspective and specific perspective is ideal in this study in order to measure the respondents purchasing intention and understanding their attitudes. A combinational approach (triangulation) views a phenomenon through different perspectives and in a sense leads to higher accurate results. Results attained through the use of the two approaches give a more comprehensive coverage of a research problem.

\section{Research Strategy}

With regards to the research approach, a questionnaire is conducted for a quantitative collection of data. A case study is excluded considering the fact that a case study focuses on individual instances rather than wider spectrums. An experiment and observation are also excluded because of the lack of time and resources.

\section{Classification of Data Used}

Primary data. Questionnaires are designed to collect information that is used subsequently as data for analysis. The questionnaire in use consists of a number of relevant questions about the respondents' attitudes and consumer's behavior. The questionnaire is semi-structured, and has a combination of closed and open questions. The arrangement of the questionnaire consists of three parts. Part A measures consumer's behavior regarding perfume. Part B measures consumer's attitudes regarding perfumes, and part $\mathrm{C}$ measures brand preference (celebrity brands vs. premium brands).

A sample of 100 was chosen and information was collected through means of convenience. The survey 
was aimed at males under the age of 25 to 35. It was therefore performed at university students and executive level targeted group. The face-to-face method was used to achieve a higher rate of response. A sent out questionnaire could have been utilized, but the time of the study is limited and the side-effect is a low rate of response.

Secondary data. Secondary data is information that has been previously gathered for some purposes other than the current research project. A large proportion of the data used in this study are classified as secondary data because of the wide availability and applicability of it. To a great extent, information was gathered from research journals, books, the internet, and research articles. With regards to the growth of the internet usage, a lot of the data collected were extensively available in electronic format.

\section{Reliability and Validity}

Reliability. Reliability is often referred to a measurement that is stable and has not been exposed to coincidental influences. The research instrument should produce the same data whether it is done today or re-done at another time point.

Validity. The term validity often refers to the relevance of the data in relation to the research phenomena. The research instrument used as a measurement of phenomena should measure exactly what it means to measure. In a sense, a high validity means that the data and methods are right and relevant.

\section{Data Analysis}

\section{The Survey and Data}

The questionnaire was circulated among 100 respondents selected from Colombo and Gampaha in order to gather data on the nature of influence of the consumer buying intention in relation to celebrity endorsement.

\section{Analysis the Data}

Analysis of consumer buying intention. Consumer buying intention towards celebrity endorsement and the variables of consumer buying intention are discussed here. There are selecting, purchasing, using, evaluating, and disposing. Frequencies of decisions and their percentages for each variable according to various categories are presented.

\section{The Influence of Consumer Buying Intention}

According to the first objective of this study, whether the celebrity endorsement can influence the consumer buying intention, the buying intention was measured using the frequency of selecting, purchasing, using, evaluating, and disposing. The responses from consumer buying intention on this matter were obtained from respective questions.

\section{The Variables of Consumer Buying Intention}

The second objective of this study is to find out the most influential decision of consumers among selecting, purchasing, using, evaluating, and disposing with regard to celebrity endorsement advertising. In order to find out the most influential decision, the respondents who are strongly influenced by celebrity endorsement advertising and the respondents who are moderately influenced are taken into consideration.

As shown in Table 3 and Figure 2, the age group of 18-22 is the maximum representation of this survey study, while Black Knight has been the most popular perfume brand in all most all the subjects' choice. Adidas has been the second most interested perfume brand when Pro Sport has been the next popular brand in this study. 
Table 3

Age Group

\begin{tabular}{|c|c|c|c|c|c|c|c|c|c|c|c|}
\hline \multicolumn{12}{|c|}{$\begin{array}{ll} & \text { Count } \\
\end{array}$} \\
\hline & \multicolumn{10}{|c|}{ Which perfume/perfumes brand do you recall when you buying of the given time period? } & \multirow[t]{2}{*}{ Tota } \\
\hline & $\begin{array}{l}\text { Black } \\
\text { Knight }\end{array}$ & Play boy & Polo & $\begin{array}{l}\text { Calvin } \\
\text { Klein }\end{array}$ & $\begin{array}{l}\text { Armani } \\
\text { Code }\end{array}$ & Adidas & $\begin{array}{l}\text { Hugo } \\
\text { boss }\end{array}$ & Blue & $\begin{array}{l}\text { Pro } \\
\text { sport }\end{array}$ & other & \\
\hline $18-22$ & 15 & 0 & 0 & 0 & 0 & 4 & 0 & 1 & 2 & 5 & 27 \\
\hline $23-28$ & 11 & 1 & 0 & 1 & 1 & 4 & 1 & 1 & 2 & 8 & 30 \\
\hline $29-34$ & 6 & 2 & 1 & 2 & 1 & 2 & 0 & 0 & 3 & 6 & 23 \\
\hline Above 35 & 8 & 1 & 0 & 0 & 1 & 4 & 1 & 2 & 1 & 2 & 20 \\
\hline Total & 40 & 4 & 1 & 3 & 3 & 14 & 2 & 4 & 8 & 21 & 100 \\
\hline
\end{tabular}

Source: survey data 2014.

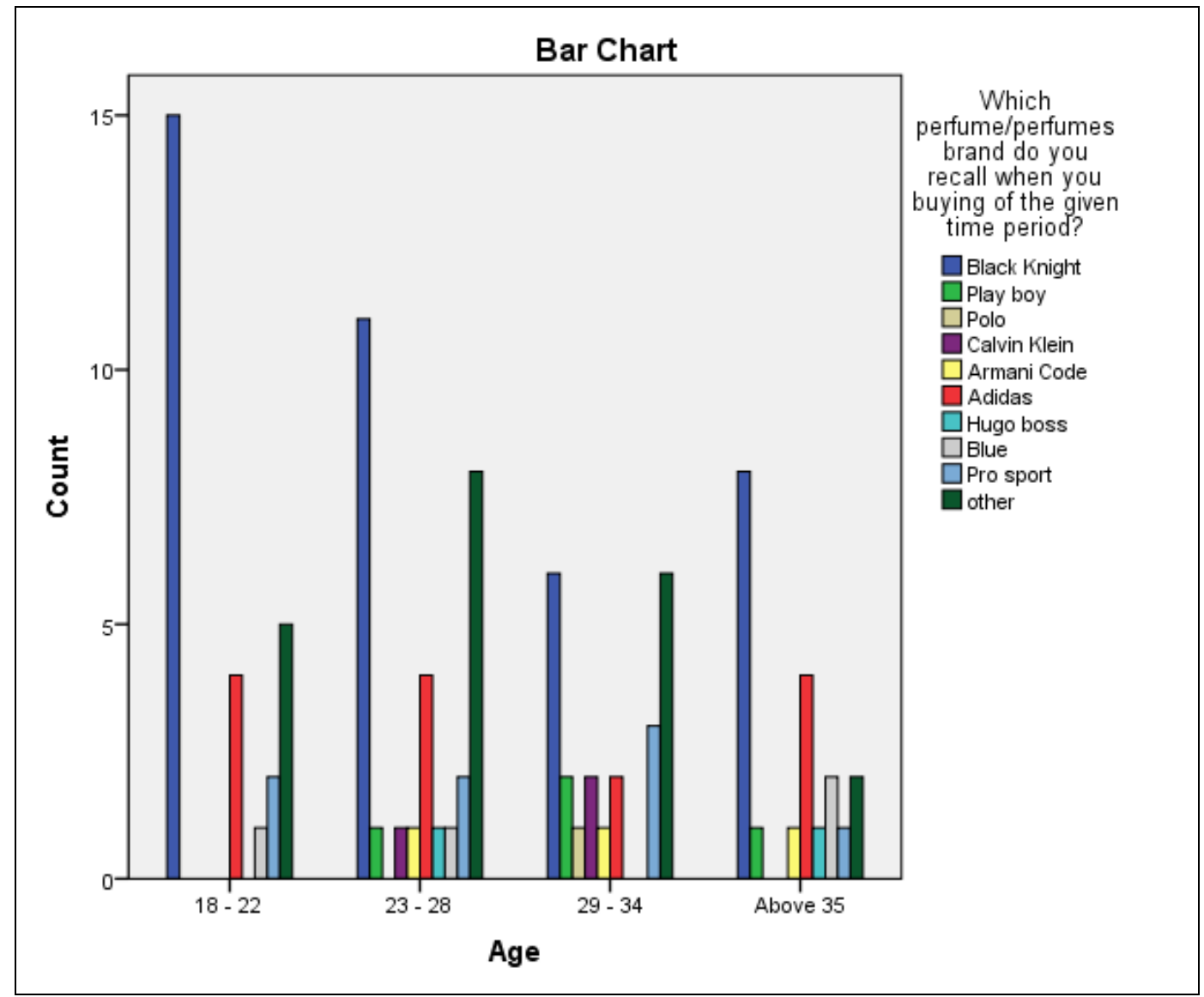

Figure 2. Age group. Source: survey data 2014.

When it comes to the occupation (Figure 3 and Table 4) and how this factor relate to the choice of perfume with the celebrity influence, the students who aged between 18-22 have the highest rate of interest with the celebrity influence in their perfume purchasing, while executives and professionals place respectively. 


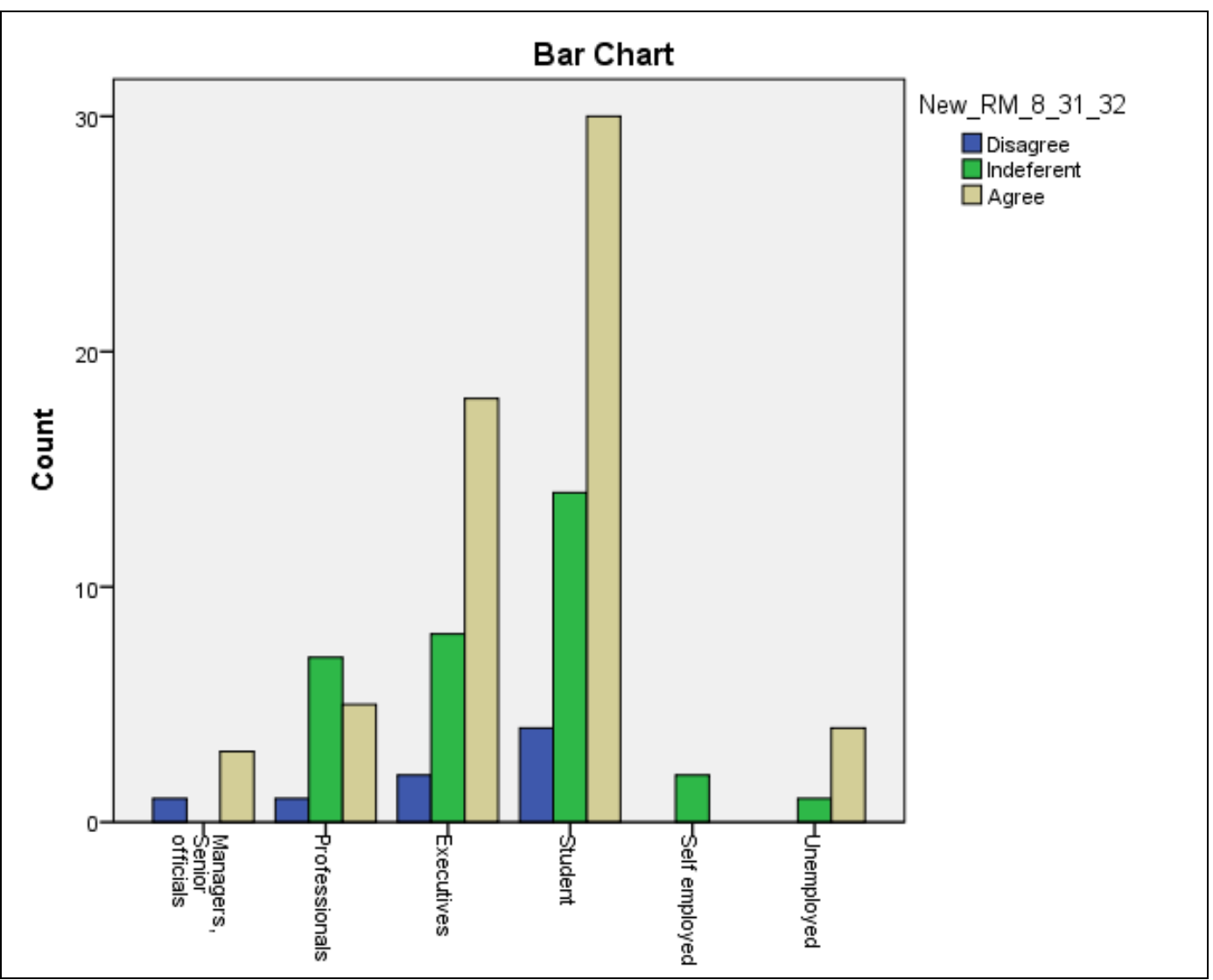

Figure 3. Occupation, celebrity, and influence. Source: survey data 2014.

Table 4

Occupation, Celebrity, and Influence

\begin{tabular}{|c|c|c|c|c|c|}
\hline \multicolumn{6}{|c|}{ Occupational group * New_RM_8_31_32 crosstabulation } \\
\hline \multicolumn{6}{|c|}{ Count } \\
\hline & & \multicolumn{3}{|c|}{ New_RM_8_31_32 } & \multirow{2}{*}{-Total } \\
\hline & & Disagree & Indeferent & Agree & \\
\hline \multirow{6}{*}{ Occupational group } & Managers, senior officials & 1 & 0 & 3 & 4 \\
\hline & Professionals & 1 & 7 & 5 & 13 \\
\hline & Executives & 2 & 8 & 18 & 28 \\
\hline & Student & 4 & 14 & 30 & 48 \\
\hline & Self employed & 0 & 2 & 0 & 2 \\
\hline & Unemployed & 0 & 1 & 4 & 5 \\
\hline Total & & 8 & 32 & 60 & 100 \\
\hline
\end{tabular}

Source: survey data 2014.

Degree and other professional qualification have been the significant educational qualifications in this sample while they have expressed that celebrity endorsement in the perfume brands influences their perfume buying behavior. 


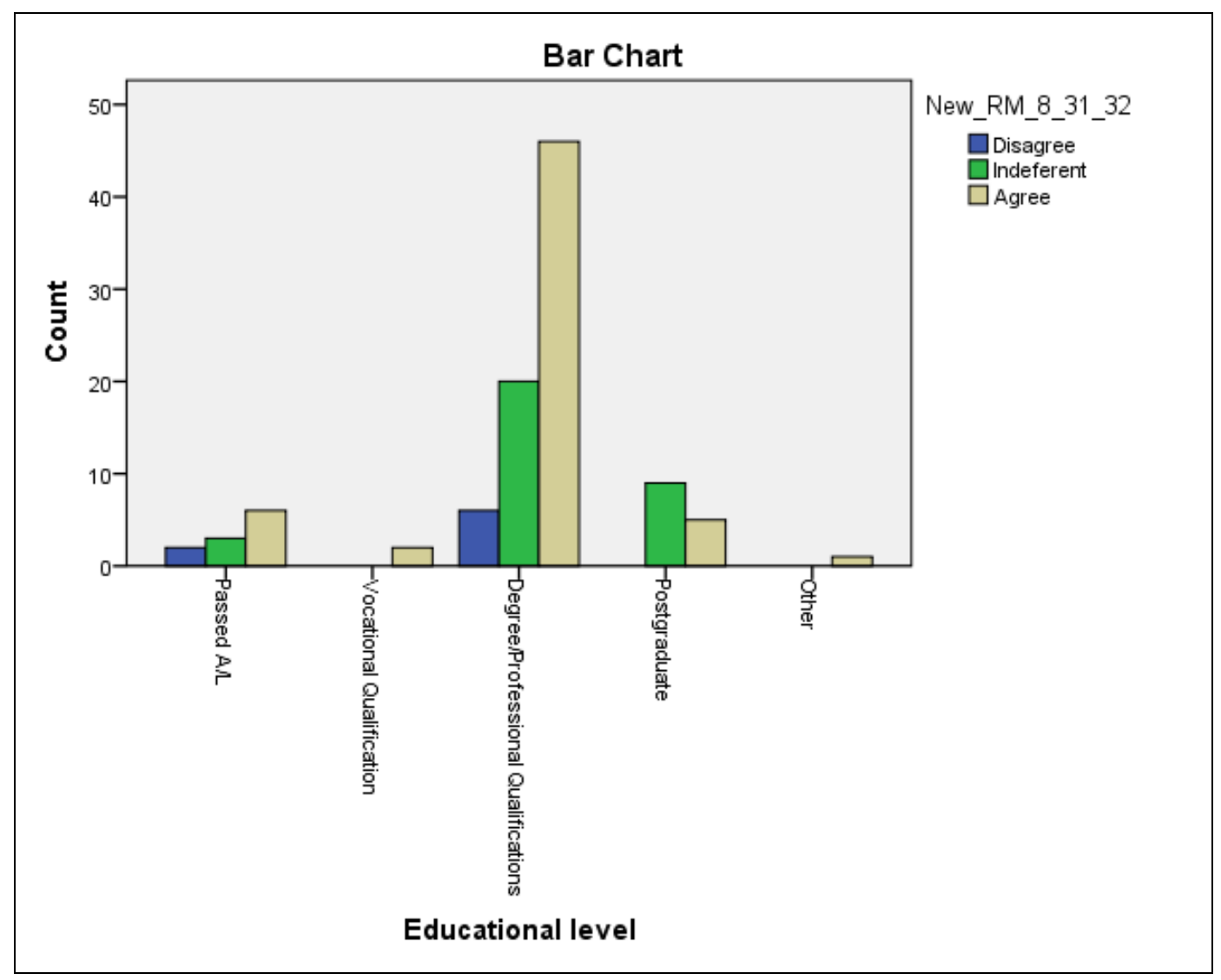

Figure 4. Educational level, celebrity, and influence. Source: survey data 2014.

Table 5

Educational Level, Celebrity, and Influence

\begin{tabular}{|c|c|c|c|c|c|}
\hline \multicolumn{6}{|c|}{ Educational level * New_RM_8_31_32 crosstabulation } \\
\hline \multicolumn{6}{|c|}{ Count } \\
\hline & & \multicolumn{3}{|c|}{ New_RM_8_31_32 } & \multirow{2}{*}{-Total } \\
\hline & & Disagree & Indifferent & Agree & \\
\hline \multirow{5}{*}{ Educational level } & Passed A/L & 2 & 3 & 6 & 11 \\
\hline & Vocational qualification & 0 & 0 & 2 & 2 \\
\hline & Degree/Professional qualifications & 6 & 20 & 46 & 72 \\
\hline & Postgraduate & 0 & 9 & 5 & 14 \\
\hline & Other & 0 & 0 & 1 & 1 \\
\hline Total & & 8 & 32 & 60 & 100 \\
\hline
\end{tabular}

Source: survey data 2014.

According to the data analyzed (Figure 5), smell is the most important fact that influences subjects' buying behavior when commercial advertisement can be another factor in motivation. And their personal interesting has also another factor in this.

Moreover, following Figure 6 communicates the way respondents reveal their personal ideas referring to the above factors in the hypotheses. 


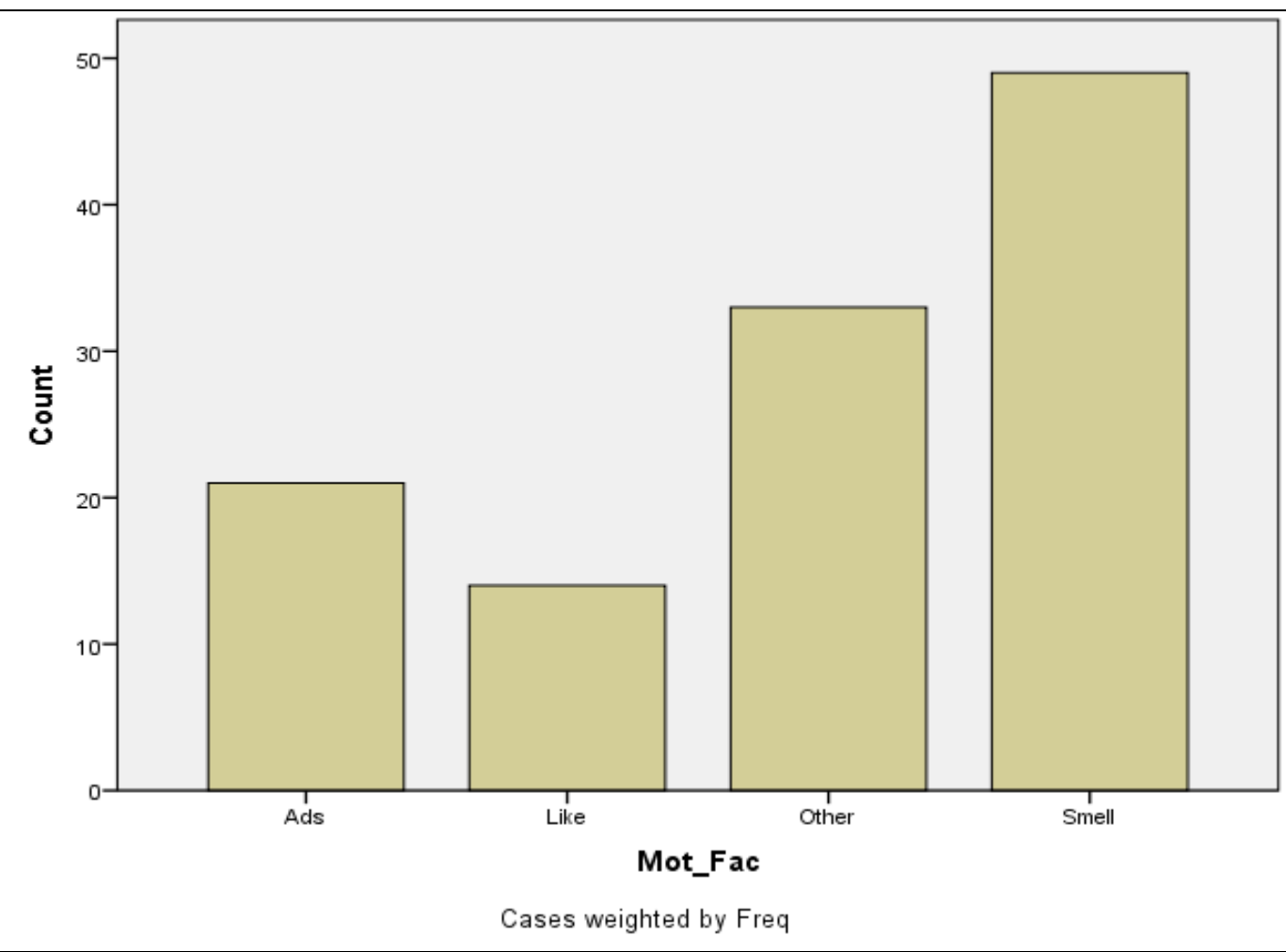

Figure 5. Perfume purchase and motivation. Source: survey data 2014.

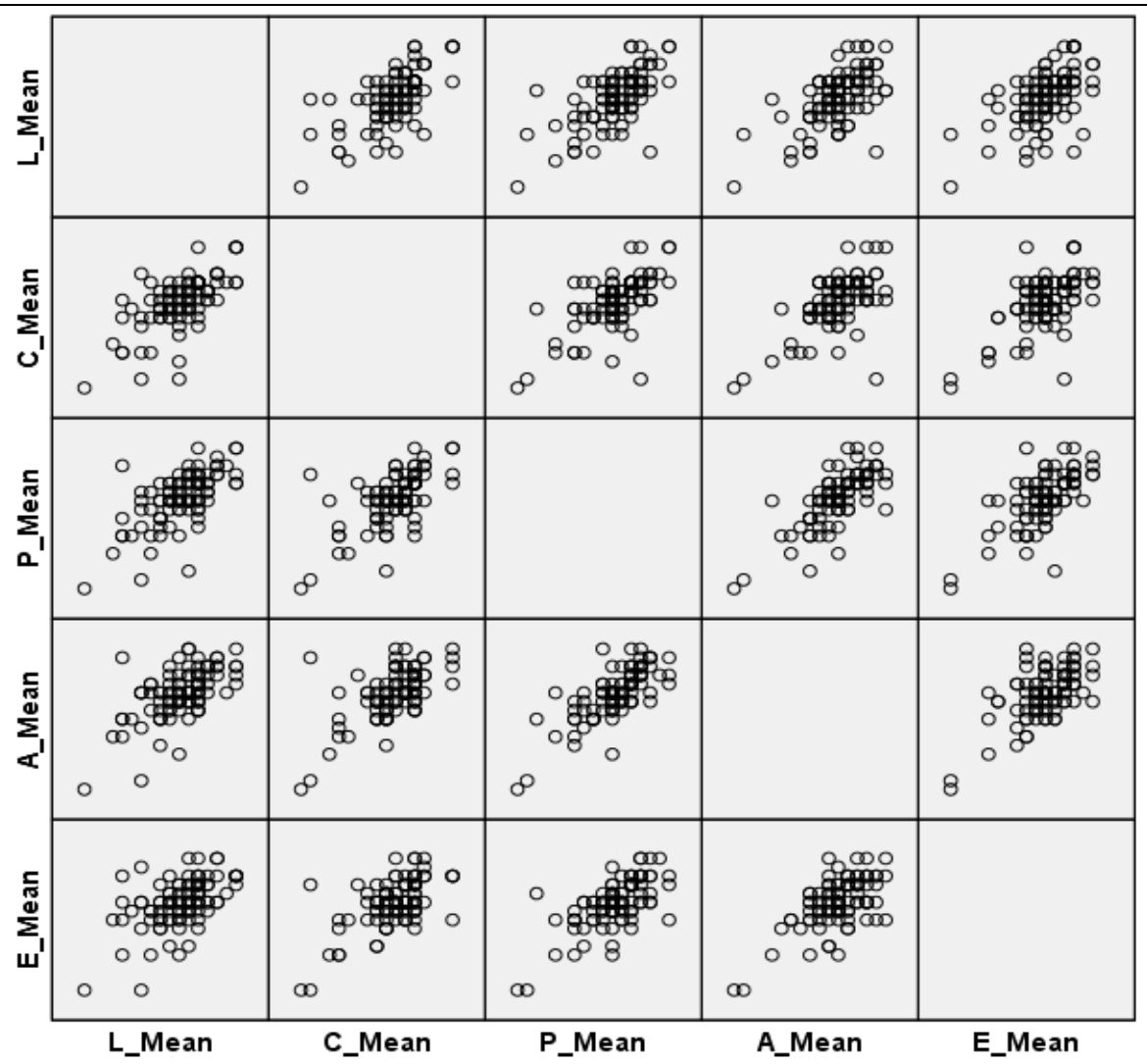

Figure 6. Characteristics of celebrity endorsement; likability, credibility, personality, attractiveness, and expertise. 
Table 6

Characteristics of Celebrity Endorsement: Likability, Credibility, Personality, Attractiveness, and Expertise

\begin{tabular}{|c|c|c|c|c|c|c|}
\hline \multicolumn{7}{|c|}{ Correlations } \\
\hline & & L_RMean & C_RMean & P_RMean & A_RMean & E_RMean \\
\hline \multirow{3}{*}{ L_RMean } & Pearson correlation & 1 & $0.550 * *$ & $0.557 * *$ & $0.542 * *$ & $0.446 * *$ \\
\hline & Sig. (2-tailed) & & 0.000 & 0.000 & 0.000 & 0.000 \\
\hline & $\mathrm{N}$ & 100 & 100 & 100 & 100 & 100 \\
\hline \multirow{3}{*}{ C_RMean } & Pearson correlation & $0.550 * *$ & 1 & $0.594^{* *}$ & $0.609 * *$ & $0.533 * *$ \\
\hline & Sig. (2-tailed) & 0.000 & & 0.000 & 0.000 & 0.000 \\
\hline & $\mathrm{N}$ & 100 & 100 & 100 & 100 & 100 \\
\hline \multirow{3}{*}{ P_RMean } & Pearson correlation & $0.557 * *$ & $0.594 * *$ & 1 & $0.629 * *$ & $0.568 * *$ \\
\hline & Sig. (2-tailed) & 0.000 & 0.000 & & 0.000 & 0.000 \\
\hline & $\mathrm{N}$ & 100 & 100 & 100 & 100 & 100 \\
\hline \multirow{3}{*}{ A_RMean } & Pearson correlation & $0.542 * *$ & $0.609 * *$ & $0.629 * *$ & 1 & $0.537 * *$ \\
\hline & Sig. (2-tailed) & 0.000 & 0.000 & 0.000 & & 0.000 \\
\hline & $\mathrm{N}$ & 100 & 100 & 100 & 100 & 100 \\
\hline \multirow{3}{*}{ E_RMean } & Pearson correlation & $0.446 * *$ & $0.533 * *$ & $0.568 * *$ & $0.537 * *$ & 1 \\
\hline & Sig. (2-tailed) & 0.000 & 0.000 & 0.000 & 0.000 & \\
\hline & $\mathrm{N}$ & 100 & 100 & 100 & 100 & 100 \\
\hline
\end{tabular}

Note. ${ }^{* *}$ Correlation is significant at the 0.01 level (2-tailed). Source: survey data 2014.

\section{Hypotheses}

Hypothesis 1: The celebrity endorser's perceived likability will positively influence purchase intention for consumers.

Hypothesis 2: The celebrity endorser's perceived credibility will positively influence purchase intention for consumers.

Hypothesis 3: The celebrity endorser's perceived personality will positively influence purchase intention for consumers.

Hypothesis 4: The celebrity endorser's perceived attractiveness will positively influence purchase intention for consumers.

Hypothesis 5: The celebrity endorser's perceived expertise will positively influence purchase intention for consumers.

In the data analysis related to above hypotheses, it was revealed that the likability to the celebrity used in the perfume brand is highly significant in the perfume buying intention. However, the other factors of familiar face and life style of the celebrity used in the perfume brand has not been significant in this research study.

\section{Conclusion and Recommendation}

\section{Conclusion}

This research identified factors from the influence of the consumer buying intention in relation to celebrity endorsement advertising in Sri Lanka. The study was limited to the TV advertisements.

Based on theoretical background and literature as well as the assumptions made by the researcher, the study formulated the conceptual frame work. In this process, only five attributes of celebrities were taken into consideration. These five attributes are likability, credibility, personality, attractiveness, and expertise. From the conceptual model, the researcher attempted to build a relationship between the celebrity endorsement and the 
consumer buying intention. The celebrity endorsers were considered as independent variable and the consumer buying intention was the considered as the dependent variable.

The researcher hypothesized that there is a relationship between the celebrity and the consumer buying intention. Further, this relationship can vary according to the core components of the independent variable. Under the indicators measurement, criteria were developed to identify the research variables. The study tested five hypotheses based on the independent variable and its core components to examine the influence of the consumer buying intention.

The data were collected through structured questionnaire. A sample of 100 respondents was selected for the survey from Colombo and Gampaha. The respondents were selected according to the random sampling method.

In the data analysis related to above hypotheses, it was revealed that the likability to the celebrity used in the perfume brand highly significant in the perfume buying intention. However, the other factors of familiar face and life style of the celebrity used in the perfume brand have not been significant in this research study.

\section{Recommendation}

The research examined celebrity endorsement on the basis of five determinants. It could be interesting to elaborate more on one of these indirect determinants, in order to obtain a broader foundation of knowledge with respect to the celebrity endorsement. Additionally, incorporating the above mentioned distinctions could provide other insights in this field of knowledge. It could, for example, be the case that specific determinants of celebrity endorsement generate consumer's buying intention more than others.

The consumers can recall the advertisements because of the attractiveness of the celebrities. If the marketers want to keep the advertisement in the consumer's mind the attractive celebrity is more effective.

The influence of consumer buying intention behavior can be changed according to the type of celebrity as well as the product category.

The attractive celebrity is more effective for impulsive goods.

The celebrity used in advertisements should have following attributes and qualifications in order to yield effective results. He or she:

(1) should have knowledge about the advertised product;

(2) should use the product;

(3) should have good image;

(4) should have presentation skills;

(5) should be relevant to the product.

\section{Areas for Further Research}

This study emphasizes the need that future researchers should pay more attention on this field. This is an interesting field for researchers; however, it has been neglected by Sri Lankan researchers.

(1) Future research could also take into account issues like: celebrity overshadowing, overexposure, overuse, and extinction of the celebrity endorser.

(2) Negative impact of celebrity endorsement.

(3) This study focused only on celebrities' five attributes, i.e. likability, credibility, personality, attractiveness, and expertise. More studies are necessary for other attributes such as popularity, talented, similarity, familiarity, and match-up congruence. 
(4) Only TV advertisements were selected for this study. Another study can examine the influence of consumer buying intention in relation to celebrity advertising for other media.

This study did not examine influence of consumer buying intention according to the consumer's demographic factors. Further research must be needed to find out the relationship between the influence of consumer buying intention and demographic factors in relation to celebrity endorsement.

\section{References}

Aaker, J. (1997). Dimensions of brand personality. Journal of Marketing Research, 34(3), 347-356.

Amos, C., Holmes, G., \& Strutton, D. (2008). Exploring the relationship between celebrity endorser effects and advertising effectiveness: A quantitative synthesis of effect size. International Journal of Advertising, 27(2), 209-234.

Belch, G. E., \& Belch, M. A. (2008). Advertising and promotion: An integrated marketing communication perspective (6th ed.). New York.

Byrne, A. W., \& Breen, M. S. (2003). The Naked truth of celebrity endorsement. British Food Journal, 105(4), 288-296.

Cohen, J. B., \& Golden, E. (1972). Informational social influence and product evaluation. Journal of Applied Psychology, 56, 54-59.

Dissanayaka, R., \& Ismail, N. (2015). Relationship between celebrity endorsement and brand attitude: With reference to financial services sector brands in Sri Lanka. Conference Proceeding of 6th International Conference on Business and Information 9 (ICBH), pp. 472-487.

Erdogan, B. Z. (1999). Celebrity endorsement: A literature review. Journal of Marketing Management, 15(4), 291-314.

Escalas, J. E., \& Bettman, J. R. (2010). Connecting with celebrities: Celebrity endorsement, brand meaning, and self-brand connections. Journal of Marketing Research. Under review (second round).

Freud, S. (1922). The unconscious. The Journal of Nervous and Mental Disease, 56(3), 291-294.

Friedman, H. H., \& Friedman, L. (1979). Endorser effectiveness by product type. Journal of Advertising Research, 19(5), 63-71.

Goldsmith, R. E., Lafferty, B. A., \& Newell, S. J. (2000). The impact of corporate credibility and celebrity credibility on consumer reaction to advertisements and brands. Journal of Advertising, 29(3), 43-54.

Hovland, C. I., \& Weiss, W. (1953). The influence of source credibility on communication effectiveness. Public Opinion Quarterly, 15, 635-650.

Hunter, E., \& Davidsson, P. (2008). Celebrity entrepreneurship: The effect of negative celebrity information on the new venture. In Babson College Entrepreneurship Research Conference, 5-7 June 2008, The University of North Carolina, Chapel Hill.

Jinadasa, M. (2015). Internet through mobile phone and its cognitive and behavioral impact: Changing sexuality. Journalism and Mass Communication, 5(12), 614-628.

Jinadasa, M. (2016a). Psychological and philosophical readings of the spectatorship of bollywood and Indian Tamil film in Sri Lanka. Journalism and Mass Communication, 6(4), 201-212.

Jinadasa, M. (2016b). Representation of youth generation in the mobile phone and internet media in Sri Lanka. Psychology Research, 6(5), 311-317.

Jinadasa, M. P. K. (2009). Sannevedana addyanaya (Understanding Media \& Communication) Colombo: Godage \& Brothers Publishers.

Jinadasa, M. P. K. (2011a). Development communication; theory and practice. Colombo: Godage International Publishers (PVT) LTD.

Jinadasa, M. P. K. (2011b). Madya ha nawa madya ithihasaya (History of Media and New Media). Kadawatha: Jayavi Printers. Jinadasa, M. P. K. (2013). Jathyantara Sanniwedanaya (International Communication). Colombo: Godage \& Brothers Publishers. Jinadasa, M. P. K. (2014a). Bhashawa ha Sanniwedanaya (Language and Communication). ICCR, Madamahanuwara.

Jinadasa, M. P. K. (2014b). Sanwardana Sanniwedanaya (Development Communication). ICCR, Madamahanuwara.

Jinadasa, W. W. M. P. K. (2015). Community development programmes and folk-media: A communication model for Sri Lankan rural society. Global Media Journal_-Indian Edition, 2(2). India.

Johnson, W. L., \& Johnson, A. B. (1995). Using SAS/PC for higher order factoring. Educational and Psychological Measurement, 55, 429-434.

Kahle, L. R., \& Homer, P. M. (1985). Physical attractiveness of celebrity endorser. A social adaptation perspective. Journal of Consumer Research, 2, 954-961. 
Kelman, H. C. (1961). Process of opinion change. Public Opinion Quarterly, 25, 57-58.

Khatri, P. (2006). Celebrity endorsement: A strategic promotion perspective. Indian Media Studies Journal, 1(1).

Klebba, J. M., \& Unger, L. S. (1983). The impact of negative and positive information on source credibility in a field setting. NA-Advances in Consumer Research, Volume 10. In R. P. Bagozzi, A. M. Tybout, and A. Abor (Eds.), MI: Association for Consumer Research, pp. 11-16.

Lasswell, H. D. (1965). World politics and personal insecurity. New York: Free Press.

McCracken, G. (1989). Who is the celebrity endorser? Cultural foundations of the endorsement process. Journal of Consumer Research, 16(12), 310-321.

McGuire, W. J. (1985). Attitudes and attitude change. Handbook of Social Psychology, 2, 233-346.

Money, R. B., Shimp, T. A., \& Sakano, T. (2006). Celebrity endorsements in Japan and the Unites States: Is negative information all that harmful? Journal of Advertising Research, 26(1), 113-123.

Mukherjee, D. (2009). Impact of celebrity endorsements on brand image. Abstract from Social Science Research Network, Electronic Paper Collection.

Ohanian, R. (1991). The impact of celebrity spokespersons' percieved image on consumers' intention to purchase. Journal of Advertising Research, 31(1), 46-53.

Saleem, F. (2007). Young adult perception towards celebrity endorsement: A comparative study of single celebrity and multiple celebrities endorsement. European Journal of Economics, Finance and Administrative Sciences, 8, 128-139.

Schlecht, C. (2003). Celebrities' impact on branding. Retrieved from http://worldlywriter.com/images/portfolio/Proposals/Celebrity_Branding.pdf

Shaughnessy, O. J. (1995). Competitive marketing: A strategic approach (3rd ed.). Academic Edition of Unwin Hyman.

Silvera, D. H., \& Austad, B. (2004). Factors predicting the effectiveness of celebrity endorsement advertisements. European Journal of Marketing, 38(11/12), 1509-1526.

Solomon, M. R. (2002). Consumer behaviour: Buying, having, being (5th ed.). New Jersey: Prentice Hall.

Speck, P. S., Schumann, D. W., \& Thompson, C. (1988). Celebrity endorsement-scripts, schema and roles: Theoretical framework and preliminary tests. Advances in Consumer Research, 15, 68-76.

Wenqian Gan, B. A. (2006). Effectiveness of celebrity endorsement advertising in Chinese marketplace. Dissertation submitted for MA in Marketing.

Weerasiri, S., \& Wanninayaka, W. M. C. B. (2016). Impact of the celebrity endorsement on the consumer buying behaviour. Global Illuminators. Bangkok, Thailand.

Woodside, G., \& Davenport, J. W. (1974). The effect of salesman similarity and expertise on consumer purchasing behaviour. Journal of Marketing Research, 11, 198-202. 